\title{
Rehabilitation medicine for elderly patients, a further note
}

\author{
Masiero $S$ and Musumeci $A^{*}$ \\ Section of Physical Medicine and Rehabilitation, Department of Neuroscience, University of Padova, Italy
}

\begin{abstract}
Increased life expectancy of a large percentage of a population has many implications, specifically for older olds and their families. Beside the social burden, it means increasing costs for managements for public and private health system. The recent book, "Rehabilitation Medicine for Elderly Patients", offers insight into the complex world of older persons (healthy, frail, diseased or dying) from the perspective of Physical Medicine and Rehabilitation, but approaching matters from a variety of viewpoints. Written primarily for junior doctors and residents, it is a comprehensive educational tool, easy to read, and written in a structured way. A list of useful references is here added, specifically for the neurorehabilitation of aging and early aging patients. It may help physiatrists and general practitioners to assist patients with disabling conditions.
\end{abstract}

World older population is rapidly growing in number and proportion and people over 60 years are expected to double in the next few decades. The European continent is projected to remain for at least the next 50 years the world's area with the oldest population: by 2050 about $37 \%$ of Europeans is expected to be 60 or over. Increased life expectancy that reflects, also the success of public health interventions, has many implications: the growing number of older persons suffering of chronic diseases increases demands on the public healthcare system, costs for management, and social burden. Sarcopenia, frailty, falls, and dizziness, are just some of the common medical conditions that occur among the elderly, diminishing their quality of life (QOL) and contributing to their physical and cognitive decline, disability and death. However, ageing itself should not be considered a disease and many interventions by governments, communities and families may promote health, participation, social inclusion and security of older people and improve their QOL. The elderly (of whom $60-75 \%$ are healthy, $20-30 \%$ suffer from chronic diseases, and 2-10\% are "frail") should benefit from health-related targeted measures applied in the different contexts in which they live (home, residences, hospitals). It is in this regard that the book, Rehabilitation Medicine for Elderly Patients [1], offers insight into the complex world of older in the specialty of Physical Medicine and Rehabilitation (PM\&R), but approaching matters from a of variety of viewpoints. The new book represents the perspective of international leaders on both updated literature review (including experimental and biomedical approaches) and practical clinical applications to ensure high quality standard to the contents. Rehabilitation Medicine for Elderly Patients is organized into three parts: Part I is general and deals with many issues of elderly people such as sarcopenia, frailty, exercise, nutrition, new technologies, and therapeutics. Part II is on rehabilitation of the most commonly encountered diseases of seniors. Some innovative topics covered in this part are cognitive therapy, spinal lesions, sexual dysfunction rehabilitation, etc. Part III is devoted to description of different organization of healthcare system for the elderly in European countries. The book is written primarily for junior doctors, who are about to embark on their studies, and residents. It is a comprehensive educational tool, simple, easy to read, clear, and written in a structured way. It can also help physiatrists in reviewing the main topics in the field of rehabilitation, general practitioners and physicians of other specialties in assisting patients with disabling conditions. The first edition, like all first attempts, has limitations. Nonetheless, we hope it will be appreciated as a resource for training and education in the field of PM\&R and beyond. To this purpose a list of useful references is here added [2-32], specifically for neurorehabilitation of aging and early aging patients.

\section{Conflicts of interest}

The authors declare none conflict of interest regarding the publication of this paper.

\section{Funding statement}

None

\section{Acknowledgments}

Funding: None

\section{References}

1. Rehabilitation Medicine for Elderly Patients, Masiero S, Carraro U, Eds. ISBN 978 3-319-57405-9 ISBN 978-3-319-57406-6 (eBook) DOI 10.1007/978-3-319-57406-6.

2. Gava P, Kern H, Carraro U (2015) Age-associated power decline from running, jumping, and throwing male masters world records. Exp Aging Res 41: 115-135. [Crossref]

${ }^{\star}$ Correspondence to: Alfredo Musumeci, Department of Neuroscience, Section of Physical Medicine and Rehabilitation, University of Padova, Padova, Italy, E-mail: alfredomusumeci@yahoo.com

Key words: rehabilitation, medicine, healthy elderly, frail patients Special Issue: Assisted Exercise

Ugo Carraro

Interdepartmental Center of Myology

University of Padova

Italy

Alfredo Musumeci

Neuroscience Department

University of Padova \& Padova General Hospital

Italy

Received: June 07, 2018; Accepted: June 14, 2018; Published: June 19, 2018 
3. Kern H, Hofer C, Loefler S, Zampieri S, Gargiulo P, et al. (2017) Atrophy, ultrastructural disorders, severe atrophy and degeneration of denervated human muscle in SCI and Aging. Implications for their recovery by Functional Electrical Stimulation, updated 2017. Neurol Res 39:660-666.

4. Carraro U, Kern H, Gava P, Hofer C, Loefler S, et al. (2015) Biology of Muscle Atrophy and of its Recovery by FES in Aging and Mobility Impairments: Roots and By-Products. Eur J Transl Myol 25: 221-30. [Crossref]

5. Kern H, Carraro U (2014) Home-Based Functional Electrical Stimulation for LongTerm Denervated Human Muscle: History, Basics, Results and Perspectives of the Vienna Rehabilitation Strategy. Eur J Transl Myol 24:3296.

6. Carraro U, Kern H, Gava P, Hofer C, Loefler S, et al. (2017) Recovery from muscle weakness by exercise and FES: lessons from Masters, active or sedentary seniors and SCI patients. Aging Clin Exp Res 29:579-590 [Crossref]

7. Sajer S (2017) Mobility disorders and pain, interrelations that need new research concepts and advanced clinical commitments. Eur J Transl Myol 27:7179. [Crossref]

8. Boncompagni S, Kern H, Rossini K, Hofer C, Mayr W, et al. (2007) Structural differentiation of skeletal muscle fibers in the absence of innervation in humans. Proc Natl Acad Sci U S A. 104: 1933919344. [Crossref]

9. Kern H, Carraro U, Adami N, Hofer C, Loefler S, et al. (2010) One year of home-based daily FES in complete lower motor neuron paraplegia: recovery of tetanic contractility drives the structural improvements of denervated muscle. Neurol Res. 32: 26-31. [Crossref]

10. Kern H, Carraro U, Adami N, Biral D, Hofer C, et al. (2010) Home-based functional electrical stimulation rescues permanently denervated muscles in paraplegic patients with complete lower motor neuron lesion. Neurorehabil Neural Repair 24: 709-721. [Crossref]

11. Available at: https://www.schuhfried.com/umbraco/Surface/AuthenticationSurface/ Login?return Url=\%2Fportal

12. Albertin G, Hofer C, Zampieri S, Vogelauer M, Löfler S, et al. (2018) In complete SCI patients, long-term functional electrical stimulation of permanent denervated muscles increases epidermis thickness. Neurol Res. 40:277-282. [Crossref]

13. Gargiulo P, Reynisson PJ, Helgason B, Kern H, Mayr W (2011) Muscle, tendons, and bone: structural changes during denervation and FES treatment. Neurol Res 33: 750758. [Crossref]

14. Carraro U, Edmunds KJ, Gargiulo P, et al. (2015) 3D False Color Computed Tomography for Diagnosis and Follow-Up of Permanent Denervated Human Muscles Submitted to Home-Based Functional Electrical Stimulation. Eur J Transl Myol 25:5133. [Crossref]

15. Carraro U (2018) Muscle and skin improve by home-based FES and full-body in-bed gym. Biol Eng Med, 2018 doi: 10.15761/BEM.1000S1003 3: 4-4.

16. Edmunds KJ, Gíslason MK, Arnadottir ID, Marcante A, Piccione F, et al. (2016) Quantitative Computed Tomography and Image Analysis for Advanced Muscle Assessment. Eur J Transl Myol. 26:6015. [Crossref]

17. Edmunds K, Gíslason M, Sigurðsson S, Guðnason V, et al. (2018) Advanced quantitative methods in correlating sarcopenic muscle degeneration with lower extremity function biometrics and comorbidities. PLoS One 13: e0193241. [Crossref]
18. Kern H, Boncompagni S. et al. (2004) Long-term denervation in humans causes degeneration of both contractile and excitation- contraction coupling apparatus, wich is reversibile by functional electrical stimulation (FES). A role for myofiber regeneration? J Neuropathol Exp Neurol 63: 919-931.

19. Krenn M, Haller M, Bijak M, Unger E, Hofer C, et al. (2011) Safe neuromuscular electrical stimulator designed for the elderly. Artif Organs 35: 253-256. [Crossref]

20. Kern H, Barberi L, Löfler S, Sbardella S, Burggraf S, et al. (2014) Electrical stimulation counteracts muscle decline in seniors. Front Aging Neurosci. 6: 189. [Crossref]

21. Zampieri S, Pietrangelo L, Loefler S, Fruhmann H, Vogelauer M, et al. (2015) Lifelong physical exercise delays age-associated skeletal muscle decline. J Gerontol A Biol Sci Med Sci. 70: 163-173. [Crossref]

22. Mosole S, Carraro U, Kern H, Loefler S, Fruhmann H, et al. (2014) Long-term highlevel exercise promotes muscle reinnervation with age. J Neuropathol Exp Neurol. 73: 284-294. [Crossref]

23. Mosole S, Zampieri S, Furlan S, Carraro U, Löefler S, et al. (2018) Effects of Electrical Stimulation on Skeletal Muscle of Old Sedentary People. Gerontol Geriatr Med. 2018. [Crossref]

24. Mosole S, Carraro U, Kern H, Loefler S, Zampieri S. (2016) Use it or Lose It: Tonic Activity of Slow Motoneurons Promotes Their Survival and Preferentially Increases Slow Fiber-Type Groupings in Muscles of Old Lifelong Recreational Sportsmen. Eur J Transl Myol. 26:5972. [Crossref]

25. Barber L, Scicchitano BM, Musaro A (2015) Molecular and cellular mechanisms of muscle aging and sarcopenia and effects of electrical stimulation in seniors. Eur $J$ Transl Myol. 25: 231-236. [Crossref]

26. Carraro U, Karma Gava K, Baba A, Piccione F, Marcante A (2016) Fighting muscle weakness in advanced aging by takehome strategies: Safe anti-aging full-body in-bed gym and functional electrical stimulation (FES) for mobility compromised elderly people. Biol Eng Med, 1:1-4.

27. Frontera WR (2018) Physical activity and rehabilitation in elderly. In: Masiero S, Carraro U, Eds., pag. 43-52. ISBN 978-3-319-57405-9 ISBN 978-3-319-57406-6 (eBook).

28. Musumeci A, Papathanasiou JV, Lena E, Assenza C, Giordani C, et al. (2018) Physical Therapy Modalities for Older Persons. In: Masiero S, Carraro U, Eds., pag. 43-52. ISBN 978-3-319-57405-9 ISBN 978-3-319-57406-6 (eBook).

29. Musumeci A, Pignataro A, Ferlito E, Lazzari V, Zatti H, et al. (2018) Exercise for Frai Older Adults. In: Masiero S, Carraro U, Eds., pag. 43-52. ISBN 978-3-319-57405-9 ISBN 978-3-319-57406-6 (eBook)

30. Carraro U, Gava K, Musumeci A, Baba A, Piccione F, et al. (2018) Safe Antiaging Full-Body In-Bed Gym and FES for Lazy Persons: Home In-Bed Exercises for Fighting Muscle Weakness in Advanced Age. In: Rehabilitation Medicine for Elderly Patients, Masiero S, Carraro U, Eds., pag. 43-52. ISBN 978-3-319-57405-9 ISBN 978-3-31957406-6 (eBook)

31. Gargiulo P, Edmunds KJ, Arnadottir ID, Carraro U, Gíslason MK (2018) Muscle Assessment Using 3D Modeling and Soft Tissue CT Profiling.

32. Carraro U, Gava K, Baba A, Marcante A, Piccione F. To contrast and reverse skeletal muscle atrophy by Full-Body In-Bed Gym, a mandatory life-style for older olds and borderline mobility impaired persons. Springer-Nature Book: Muscle Atrophy, Junjie Xiao, Ed., in press.

Copyright: (C2018 Masiero S. This is an open-access article distributed under the terms of the Creative Commons Attribution License, which permits unrestricted use, distribution, and reproduction in any medium, provided the original author and source are credited. 